\title{
A.P.M. Ansems, Aansprakelijkheid voor medische hulpmiddelen ${ }^{*}$
}

\author{
Prof. mr. J.C.J. Dute
}

Dit boek is een bewerking van de masterscriptie Nederlands Recht waarop de auteur in 2016 cum laude afstudeerde aan de Open Universiteit Nederland. Centraal staat de vraag naar de aansprakelijkheid bij schade die de patiënt oploopt bij de toepassing van medische hulpmiddelen. Eerst wordt het wettelijke kader in kaart gebracht. Dan worden negen situaties onderscheiden waarin aansprakelijkheid in relatie tot medische hulpmiddelen aan de orde is (door Ansems 'categorieën' genoemd). Vervolgens worden die situaties geanalyseerd in het licht van de aansprakelijkheidsregels. Dan wordt ingegaan op artikel 6:77 BW, in het bijzonder de daarin opgenomen 'tenzij-formule'. Daarna wordt uit goed hulpverlenerschap een aantal eisen ('gedragsnormen') afgeleid, met inachtneming waarvan aansprakelijkheid voor medische hulpmiddelen kan worden voorkomen. Afgesloten wordt met een samenvatting ('resumé') en de conclusies.

Pièce de résistance bij de aansprakelijkheid voor medische hulpmiddelen is de tenzij-formule van artikel 6:77 BW. Deze houdt in dat bij gebruik van een ongeschikte zaak toerekening aan de hulpverlener plaatsvindt tenzij dat onredelijk is op grond van (1) de inhoud en de strekking van de aan de verbintenis ten grondslag liggende rechtshandeling, (2) de verkeersopvattingen dan wel (3) de overige omstandigheden van het geval. Ansems besteedt aan de tenzij-formule uitgebreid aandacht.

* Mr. ing. Joost A.P.M. Ansems, Aansprakelijkheid voor medische hulpmiddelen, Weert: Celsius juridische uitgeverij 2017, ISBN 978-90-8863-204-4.

** Jos Dute is hoogleraar gezondheidsrecht aan de Radboud Universiteit Nijmegen en redacteur van dit tijdschrift.
Hij wijst er allereerst op dat artikel 6:77 BW een risicoaansprakelijkheid vestigt; schuld is dus niet vereist. Dit brengt mee dat het niet nodig is dat de hulpverlener op de hoogte was van de ongeschiktheid. In dat geval kan immers - behoudens overmacht aansprakelijkheid reeds worden aangenomen op grond van artikel 6:74 jo. artikel 7:453 BW. Maar in de literatuur en de rechtspraak wordt in het kader van de medische aansprakelijkheid de grondregel van risicoaansprakelijkheid voor hulpzaken niet altijd erkend. Er wordt dan geen aansprakelijkheid aangenomen als het gebrek door de hulpverlener niet te onderkennen was. Vaak wordt daarbij verwezen naar hetgeen destijds tijdens de parlementaire behandeling over artikel 6:77 BW is gezegd.

Voor de hand ligt deze benadering niet, zo vindt Ansems. Immers, als het gebrek wel te onderkennen was (maar dit niet is gebeurd), is er sprake van schuld. Die situatie wordt reeds gedekt door artikel 6:74 BW. Door onder de tenzij-formule ook de situatie te scharen dat het gebrek door de hulpverlener niet te onderkennen was, wordt voorbijgegaan aan de risicoaansprakelijkheid die artikel 6:77 BW vestigt. In feite maakt deze benadering artikel 6:77 BW goeddeels overbodig.

Het is ook niet goed te begrijpen waarom voor hulpverleners een eigen, afwijkend regime zou moeten gelden bij gebruik van een gebrekkig hulpmiddel. Voor andere opdrachtnemers wordt immers wel van een risicoaansprakelijkheid uitgegaan. De patiënt is hiervan uiteindelijk de dupe. Bij een geslaagd beroep op de tenzij-formule zal hij zich immers tot de producent moeten wenden, met alle problemen en risico's van dien (bijvoorbeeld bij onbekendheid met de aansprakelijk te stellen producent of bij faillissement). 
Het probleem zou worden opgelost als de patiënt zich tot één aanspreekpunt zou kunnen richten. Artikel 6:77 BW, mits ruimer toegepast in de medische context, is bij uitstek geschikt om dit mogelijk te maken, aldus Ansems. De hulpverlener moet voor het gebruik van een ongeschikte hulpzaak aansprakelijk worden gehouden, ook als hem geen schuld treft. Hij kan dan de producent in vrijwaring oproepen, ter compensatie van de door hem te vergoeden schade. Het aantrekkelijke van deze oplossing is dat de hoofdzaak en de vrijwaringszaak door dezelfde rechter op basis van hetzelfde feitencomplex worden beoordeeld.

Alleen als de producent ontsnapt aan aansprakelijkheid vanwege een ontwikkelingsrisicoverweer, zou ook de hulpverlener niet aansprakelijk moeten zijn. Aansprakelijkheid kan natuurlijk ook afstuiten op het derde element van de tenzij-formule, de omstandigheden van het geval. Dit kan aan de orde zijn als de patiënt het hulpmiddel zelf heeft gekozen of als deze over de risico's van het hulpmiddel afdoende is geïnformeerd.

Naar mijn oordeel presenteert Ansems hiermee een goed overdacht en evenwichtig voorstel. Zijn boek is verder informatief en goed toegankelijk. Wel zijn de hoofdstuktitels niet altijd even gelukkig gekozen (zo heet hoofdstuk 3, waarin de verschillende situaties van aansprakelijkheid worden onderscheiden, 'Feitelijke omstandigheden'; hoofdstuk 6, waarin wordt ingegaan op de vraag hoe aansprakelijkheid te voorkomen, heeft als titel 'Gedragsnormen'). De tekst is verder verzorgd, maar soms ook wat stroef, hetgeen bij een beginnend auteur overigens geen verbazing hoeft te wekken. Belangrijker echter is: Ansems beheerst de materie en neemt overtuigend stelling. Een aanrader dus, dit boek.

Inmiddels, na het verschijnen van het boek, heeft Hof Den Haag (13 februari 2018, ECLI:NL:GHDHA: 2018:166) prejudiciële vragen gesteld aan de Hoge Raad. Het hof wil weten of de omstandigheid dat de zorgverlener ten tijde van de behandeling niet wist van het gebrek en als deskundige gebruiker dit ook niet hoefde te weten, gelet op de binnen zijn beroepsgroep aanwezige kennis, een voldoende zwaarwegend argument is om toerekening van de ongeschikte hulpzaak reeds daarom onredelijk te achten. Ook wordt gevraagd of voor toerekening van belang is dat het aansprakelijkheidsrisico is afgedekt door een verzekering en in hoeverre het ertoe doet dat de arts als deskundige de keuze voor de hulpzaak heeft gemaakt. Ten slotte legt het hof aan de Hoge Raad de vraag voor aan welke andere factoren bij een medische behandelingsovereenkomst als regel moet worden gedacht bij onredelijkheid van de toerekening in de zin van artikel 6:77 BW. Aan een richtinggevende uitspraak van de Hoge Raad bestaat mijns inziens dringend behoefte. 